integrated to the small scale lodges and service provides. The chapters have also briefly described and questioned the roles of a number of recent features of and employment possibilities associated with the tourism industry, especially those linked to the drive for sustainability and new forms of tourism in the third world. Chapter 8 defines what is implied by the term host population and examines the importance of local participation in the activity of tourism. One of book's key themes is central to a consideration of the role of local communities in tourism. The authors of the book have marked the notion of transculturation, the process by which local communities adapt themselves to the cultural mores and habits of those with whom they interact, is used to demonstrate that this interaction is not purely a case of the imposition of one set of cultural values upon another, as it is often represented in tourism analysis.

Chapter nine looks at the roles of government and supranational institutions in tourism. The importance of political analysis is tourism studies and the analysis of the external influences on national government is noted. The writers have tried to show how, even where governments have attempted to follow environmentally benign, socially and economically beneficial and culturally sensitive tourism developments, forces beyond their control have subverted the policies and have served only to emphasize seemingly ever-widening gaps.

In the final chapter, the authors have drawn several general conclusions from the discussion, and indulge in some crystal ball gazing about the future development of new tourism and its relations with economic, social cultural, political and geographical aspects of development. We also speculate on the future importance and absorption into reality of the notion of sustainability.

- Shanti POKHREL (BHUSAL)

\title{
$\bigcirc \circ$
}

Marry Shepherd Slusser: The Antiquity of Nepalese Wood Carving: A Reassessment, Published by: University of Washington Press, Seattle and London in Association with the Freer Gallery of Art and the Arthur M. Sackler Gallery, Smithsonian Institution Washington DC (2010) Page: 315 xix, ISBN 978-0-295-99029-3 (hardback) 
The text 'The Antiquity of Nepalese Wood Carving: A Reassessment' is a wonderful contribution contributed by an American cultural anthropologist Dr. Marry Shepherd Slusser, which represents the artistic richness of Nepalese history. The present text is her second contribution on Nepalese art emerged and developed in course of Nepalese history. Her first text named 'Nepal Mandala: A Cultural History of Kathmandu Valley' was published in 1982 A.D. That text was considered as one of the landmark publications related to explore and reconstruct the Nepalese history of art and culture on the basis of concrete evidences. Similarly the present text is her another sentiful contribution which helps to explore the Nepalese tradition of wood art, one of the main astonishing characteristics of the history of Nepalese art.

Nepalese cultural history begins from the Lichchavi period (300 to 750 AD) onwards according to the concrete archeological evidences. The stone sculptures made and established during this period are found here and there within Kahtmandu valley and its neighboring regions. Such stone sculptures suggest the rich tradition of art and culture prevailed in from relatively ancient period of time in the global context. But after the fall of Lichchhavi period, it is said that Nepal was unable to maintain the previous tradition of art and culture due to the political upheavals. Because of the continuous political instability, Nepal lost not only her economic prosperity but also her tradition of art and every other aspect of socio-cultural dimensions. Until the rise of Jayasthiti Malla, in 1415 A.D., the process continued. The state mechanism of Nepal was involved in power struggles and unable to maintain the artistic tradition of Lichchhavi dynasty. That is why Nepalese historians considered the period of Nepalese history both literary as well as archeological evidences, and till date the systematic and authentic history of Nepal during this era is yet absent.

But Dr. Slusser has proved such consideration incorrect. She has proved that there prevails a lot of evidences including carved wood artifacts which represent the pre-medical period and certainly can help to explore and reconstruct the systematic and authentic socio-cultural history of Nepal during 750 to 1415 A.D. She swayed Belachhe capah, Tyagah capah, Ukubaha, Tyasaha, Subaha, Bumgadhya temple, Itumbaha, Yatakhabaha, Ratneswor temple and investigate forty struts (in 
Nepali: Tundal) analyzed them applying 'Radio Carbon Test' and identified them as the struts carved during 715 to the end of 13th century. The Radio Carbon Test' is still regarded as the most significant scientific method to find out the actual date of ancient artifact. In this regard, the present text is one of the hallmark studies which can help to reconstruct the authentic history of Nepal during medieval period. Hence the text is helpful for the students as well as those who are involved to explore and reconstruct Nepalese history.

Obviously the present text is concentrated on to explore and explain the tradition of wood carving in Nepal. Dr. Slusser is successful to point out the antiquity of Nepalese wood carving on the basis of concrete evidences. The descriptions provided by the author in this text also enrich those who are interested and enthusiastic on the study of cultural development. Dr. Slusser is basically an anthropologist and her present contribution is able to prove how an anthropologist analyzes the cultural totality from diverse perspective. Wood carving is one of the branches of art and art is one component of culture complex, but through wood carving Dr. Slusser reconstructs the cultural history of Nepal.

Struts are the characteristic features and the indispensable part of "pagoda style' architecture. The text, hence, also helps to understand the pagoda architecture of Nepal. Besides it, the text also includes the short description of Nepalese tradition of architecture. Dr Slusser describes pagoda, shikhara and mainly the vihara style architecture of Nepal.

The text includes 288 beautiful figures (photos) of Nepalese wood struts illustrating the content. The text also includes citations and explanations of different words of Nepali and Newari language. Similarly it includes a long volume of appendix that contains a descriptive catalogue of figural struts, the report of 'Radio carbon Test and an article about the validity of Radio Carbon Test by Paul Jett, an expert of such test. The paper used is standard, layout is attractive, have binding proper to preserve in the library shelf either personal or institutional.

Overall the text is an important and valuable asset of Nepalese archeological and anthropological literature. It provides the insights on Nepalese tradition of art and cultural history as well. The main objective of 
the present text is to establish the antiquity of Nepalese wood carving, even then it successfully highlights the overall origin and development of Nepalese architecture, sculptural history, and the impact of Eastern school of Art on Nepalese art and architecture tradition. But Dr. Slusser's interpretation may confuse the reader because she has used the artistic terms of Newari tradition and Nepali tradition simultaneously. She equates Newari tradition of art with Nepali tradition. Newar civilization in Nepal emerged and prevailed during the Malla dynasty (also called later medieval period in Nepalese history from 1415 to 1815 A.D.). Hence to interpret the art tradition prevailed before the rise of Mallas as Newari tradition brings some confusion and seems incorrect. Similarly Dr. Sluesser is concentrated mainly on the struts to interpret the antiquity of Nepalese wood carving and reluctant to survey the other components like windows, wood sculptures, tymparum (Torana) and other wood materials used as an indispensable part of private and public house which may significantly help her to explore the antiquity of Nepalese wood carving.

To conclude, the credit goes to Dr. Sluesser to provide a beautiful contribution for Nepalese Anthropology which is successful to preview the cultural history of Nepal. I hope, she is able to bring other similar contribution which may enrich the prosperity of Nepalese anthropological literature in near future. Nepalese Anthropology is greatly indebted to her.

- Hari Kumar OJHA,

\section{0}

Aahuti (nickname) : Nepalma Varnabyabastaa ra Barga Sangharsha (Varna System and Class Struggle in Nepal). Rajendra Maharjan (ed.). Samata Foundation Lalitpur, Nepal. (1st edition, 2010), ISBN: 978-9937-8372-0-0, Pages: 219 (LV), Script: Nepali, Soft Cover, Price: NRs 250.00.

This scholarly work of Aahuti is a compilation of writings from 2051 to 2067 B.S. which has includes a piece of poem, about the book, introduction on 'Dalit Problem', Politics and Economy by Prof. Chaitanya Mishra, and ten headings from origins of Dalit to future of Dalit movement in Nepal. He has presented the deed and facts footing 